\title{
Pilomatricoma in the External Auditory Meatus: An Unusual Presentation
}

\author{
Dr. G. Prabhakar ${ }^{1}$, Dr. G V S S D. Deepak Chakravarthy² \\ ${ }^{1,}$ Professor, Dept of ENT, Alluri Sitarama Raju Academy of Medical Sciences, Eluru. \\ 2. Assistant Professor, Dept of ENT, Alluri Sitarama Raju Academy of Medical Sciences, Eluru.
}

\begin{abstract}
Pilomatricoma or Benign calcifying epithelioma of Malherbe is an uncommon lesion in the external auditory meatus, arising from the matrix cells at the base of the hair. Histologically it was characterized by the presence of ghost cells, basophilic cells and foreign body giant cells. It is a rare benign tumor, starting in the hair matrix and clinically resembling a hard subcutaneous swelling. Here we report a case of 47 year-old female with a pilomatricoma in the external auditory canal. We discuss the clinical, histopathological characteristics of pilomatricoma or calcifying epithelioma of Malherbe.
\end{abstract}

Key Words: Pilomatricoma, External Auditory Meatus, Hair matrix.

\section{Introduction}

Pilomatricomas are of ectodermal origin and arise from the outer root sheath cell of the hair follicle. Pilomatricomas usually are asymptomatic, deeply seated, firm, non tender subcutaneous masses adherent to the skin but not fixed to the underlying tissue. ${ }^{1}$ Most tumors are smaller than $3 \mathrm{~cm}$ in diameter. Pilomatricoma prognosis is generally good. In 1977, the term was changed as pilomatricoma from Calcifying epithelioma of Malherbe; to be more correct etymologically. ${ }^{2}$ Pilomatricoma, or calcifying epithelioma of Malherbe, was first described in 1880 by Malherbe and Chenantais. ${ }^{3}$ They described it as a benign subcutaneous tumor arising from sebaceous glands. In 1922, Dubreuilh and Cazenave described the unique histopathological characteristics of this neoplasm, including islands of epithelial cells and shadow cells. ${ }^{4}$ In 1961, Forbis and Helwig proposed the term pilomatricoma, to describe the condition to avoid a connotation of malignancy and denote its origin from hair matrix cells. ${ }^{5}$ We present a case of an unusual presentation of pilomatricoma in the external auditory meatus in 47 year old woman.

\section{Case Report}

A 47-year-old woman with an unremarkable medical history, presented with a nodule in the external auditory meatus. The patient had noted the nodule in the ear canal since one year duration. The lesion had begun growing over the last few months. There was no history of pain, infection or trauma. Clinical examination revealed a solitary, firm, well-circumscribed nodule located in the ear canal. Surgical excision was done and the specimen was sent to pathology lab. Since it was not commonly suspected preoperatively in the auditory canal, certain distinctive clinical features of tumor should suggest clinical diagnosis followed by histopathological confirmation.

Post operatively gross examination revealed nodular mass measuring less than one centimeter in diameter, well-circumscribed, firm and gritty to cut. Cut surface showed grayish white areas. Microscopic examination showed numerous lobules with basophilic cells in the periphery and of ghost-like squamous cells towards the center with a few anucleated cells. [Figure 1] There were numerous foreign body giant cells and foci of calcifications and a few lymphoplasmacytic infiltrates. The histopathological features were consistent with a diagnosis of pilomatricoma (benign calcifying epithelioma of Malherbe).

\section{Discussion}

Pilomatricoma is an uncommon lesion that arises from the matrix cells at the base of the hair. Since the first description of Pilomatricoma in 1880, there has been a gradual increase in understanding of the morphologic features and clinical presentation of this tumor. It was first described by Malherbe as benign calcifying epithelioma. ${ }^{3}$ Subsequently numerous ultrastructural and electron microscopic studies ${ }^{6,7}$ provided strong evidence of its origin from the matrix cells and the term "Pilomatricoma" was then coined by Forbis and Helwig keeping the histogenesis into consideration. ${ }^{5}$ Pilomatricoma has been reported not only as a benign lesion, or as a low-grade malignant lesion with a tendency to recur locally, but also as a highly malignant tumor.

Pilomatrixoma generally presents with subcutaneous red to blue mass that is fairly well circumscribed, freely movable and firm to gritty on palpation. ${ }^{8}$ Pilomatricoma is an uncommon benign tumor and frequently misdiagnosed as epidermoid or dermoid cyst, it has some distinctive clinical features that suggest the correct diagnosis. Pilomatricomas usually are asymptomatic, firm, non tender subcutaneous masses adherent to the skin 
but not fixed to the underlying tissue. Stretching of the skin over the tumor shows the "tent sign" with multiple facets and angles, a pathognomonic sign for pilomatricoma. ${ }^{9}$ In present case it was located in external auditory meatus measuring less than one centimeter.

Grossly the specimen was firm to hard, calcified in its central portion, measuring, less than one $\mathrm{cm}$ and was grayish-white in color. Histopathologically, the hematoxylin and eosin stained sections showed a tumor composed of an epithelial component exhibiting the typical population of basaloid and ghost cells. The basaloid cells were round to oval, hyperchromatic nuclei and scanty cytoplasm. The ghost cells were eosinophilic with a central unstained shadow in the site of the lost nucleus. In addition, a few multinucleated giant cells and areas of calcification were present. Based on these histopathological findings it was diagnosed as pilomatricoma.

Clinically differential diagnosis includes epidermoid cysts, dermoid cyst, sebaceous adenoma or carcinoma, juvenile xanthogranuloma, capillary hemangioma, and rhabdomyosarcoma. Although they grow slowly, they occasionally demonstrate rapid growth and may resemble keratoacanthoma. They can rarely undergo malignant transformation into pilomatrix carcinoma. ${ }^{10}$ Histopathological examination is must for confirmation of diagnosis. Computed tomography (CT) demonstrates a sharply demarcated, subcutaneous lesion of soft tissue density, with or without calcification. ${ }^{11}$ MRI may reveal a rim-enhancing lesion with small areas of signal dropout which may be consistent with calcifications. In present case CT and MRI was not performed preoperatively.

Pilomatricoma are found particularly on the head and neck region (over 50\% of cases) with a female predominance. ${ }^{12}$ Other locations include the upper extremity, trunk and lower extremity in decreasing order of frequency. A very few cases were reported in the pinna. No cases have been reported on the palms, soles or genital region. ${ }^{13}$ The present case was reported in 47 year old female who presented with a swelling in the external auditory canal. Pilomatricoma can occur at any age but demonstrates bimodal peak presentation during the first and sixth decades of life. However; $40 \%$ of cases occur in patients younger than 10 years of age and $60 \%$ of cases occur within the first two decades of life. ${ }^{14}$

\section{Conclusion}

Pilomatricoma is a rare benign neoplasm derived from hair follicle matrix cells. Review of world's literature has showed that this was a rare case of a calcifying epithelioma of Malherbe in the external auditory meatus. The clinical course is generally benign although, malignant transformations have been reported. Management includes a complete surgical excision. Recurrence is uncommon after adequate excision.

\section{References}

[1]. Rook A, Wilkinson DS, Ebling FJG. Hair follicle Tumours - Pilomatricoma, Blackwell Science (1998) pp. 1699-1700.

[2]. Arnold HL. Pilomatricoma. Arch Dermatol. 1977; 113:1303.

[3]. Malherbe A, Chenanatis J. Note sur I'epithelioma calcifiedes glandes sebacees. Prog Med.1880; 8:826-37.

[4]. Dubreuilh W, Cazenave E. De I' epithelioma calcifie: etude histolgique. Ann Dermatol Syphilol.1922; 3:257-68.

[5]. Forbis R, Jr, Helwig EB. Pilomatrixoma (calcifying epithelioma) Arch Dermatol. 1961;83:606-17.

[6]. Lever WF, Griesemer RD. Calcifying epithelioma of Malherbe: report of fifteen cases with comments on its differentiation from calicified epithelial cyst and on its histogenesis. Arch Derm Syphilol.1949;59:506-18.

[7]. Mc Gavran MH. Ultra structure of pilomatrixoma (calcifying epithelioma) Cancer. 1965;18:1445-56.

[8]. Shields JA, Shields CL, Eagle RC, Jr, Mulvey L. Pilomatrixoma of the eyelid. J Pediatr Ophthalmol Strabismus.1995;32:260-1.

[9]. Graham JL, Merwin CF. The tent sign of pilomatricoma. Cutis. 1978;22:577-80

[10]. Goufman DB, Murrell GL, Watkins DV. Pathology forum. Quiz case 2. Pilomatricoma (calcifying epithelioma of Malherbe) Arch Otolaryngol Head Neck Surg. 2001; 127:218-20.

[11]. Agarwal, R.P., Handler, S.D., Matthews, M.R., Carpentieri, D., 2001. Pilomatrixoma of the head and neck in children. Otolaryngol. Head Neck Surg. 125, 510-515.

[12]. Yencha MW. Head and neck pilomatricoma in the pediatric age group: a retrospective study and literature review. Int $\mathrm{J}$ Pediatr Otorhinolaryngol. 2001;57:123-8.

[13]. Boyd AS, Martin RW 3rd. Pathologic quiz case 1. Pilomatricoma (calcified epithelioma of Malherbe) with secondary ossification. Arch Otolaryngol Head Neck Surg. 1992;118:212-5.

[14]. Moehlenbeck FW. Pilomatrixoma (calcifying epithelioma). A statistical study. Arch Dermatol.1973;108:532-4.

Figure 1: Ghost like squamous cells in the center surrounded by basophilic cells towards periphery. [H\&E, X100] 


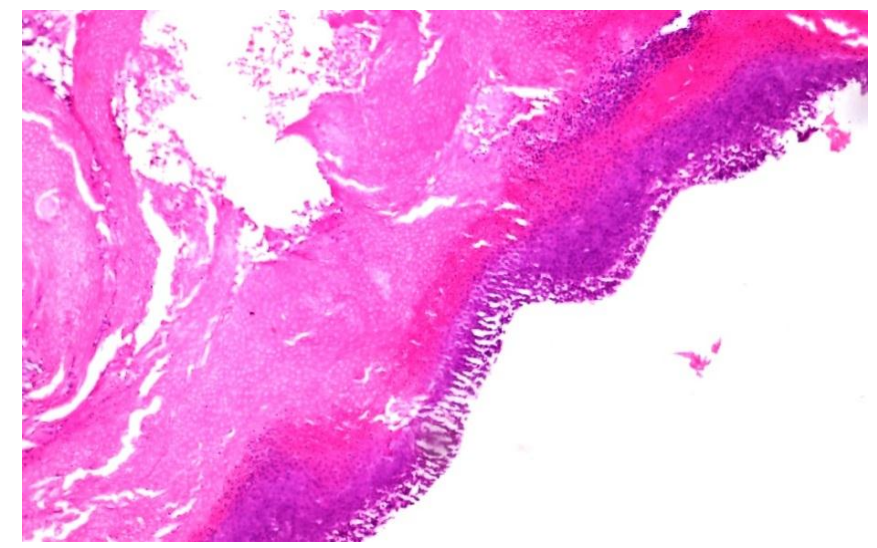

